\title{
Mortes esportivas e alegorias políticas: etnografando temores em torno dos esportes-nação
}

sport, death and political allegories: ethnography fears around a sport-oriented nation

\section{Luiz Henrique de Toledo}

\section{(2) OpenEdition}

Edição electrónica

URL: http://journals.openedition.org/aa/3519

DOI: 10.4000/aa.3519

ISSN: 2357-738X

\section{Editora}

Programa de Pós-Graduação em Antropologia Social (UnB)

\section{Edição impressa}

Data de publição: 1 junho 2019

Paginação: 253-284

ISSN: 0102-4302

\section{Refêrencia eletrónica}

Luiz Henrique de Toledo, «Mortes esportivas e alegorias políticas: etnografando temores em torno dos esportes-nação», Anuário Antropológico [Online], v.44 n. 1 | 2019, posto online no dia 06 julho 2019, consultado o 28 abril 2021. URL: http://journals.openedition.org/aa/3519 ; DOI: https://doi.org/ 10.4000/aa.3519

\section{(c) $(1)(9)$}

Anuário Antropológico is licensed under a Creative Commons Atribuição-Uso Não-Comercial-Proibição de realização de Obras Derivadas 4.0 International. 


\title{
Mortes esportivas e alegorias políticas: etnografando temores em torno dos esportes-nação ${ }^{1}$
}

\author{
Luiz Henrique de Toledo \\ Universidade Federal de São Carlos - Brasil
}

\section{Mortes esportivas}

(...) o suicídio tece entre o morto e os demais

um útil, mas irresistível parentesco.

O sujeito que se enforca, que toma formicida, que se atira da barca, não é jamais um estranho, um desconhecido (...)

Escrevi isso à propósito de Maneco, ex-craque de futebol, que, na terra em que todos devem, matou-se de paixão por uma dívida. Quarenta contos - eis a pobre, a triste,

a humilde importância que ele não pode pagar (...)

(Nelson Rodrigues 1994[1956])

Num texto bem conhecido de muitos estudiosos do futebol, intitulado $A$ morte da 'Alegria do povo', o antropólogo José Sérgio Leite Lopes e o sociólogo Sylvain Maresca (Leite Lopes \& Maresca, 1992) discutem as origens populares do estilo de jogar do futebolista Garrincha à luz dos acontecimentos desencadeados por sua morte. Deslindam desse fato inescapável os desdobramentos históricos encerrados em seu funeral, ocorrido em 1983. À queda do corpo físico, o evento de ordem natural que precipitara a discussão, seguiu-se uma análise sobre sua queda moral e, diria, política. A narrativa do evento abre-se para um inquérito histórico em que o funeral, capturado por grupos populares de torcedores, coloca em disputa a posse aflita pelo corpo inerte do ídolo, que vivera os últimos anos de sua vida sob severas condições de privação material, apagamento de sua biografia esportiva e sociabilidade humilhante. É como se pudesse dizer que Garrincha morrera muitas vezes antes mesmo do destino inevitável.

$\mathrm{Na}$ época que estava em atividade, termos como ídolo, craque, fora de série compunham o repertório de adjetivações que acompanhavam seu nome. Se tivesse jogado a partir dos anos 1990, possivelmente seria chamado de "mito", termo que se popularizou posteriormente para designar atletas, mas não somente, de altíssima perfor- 
mance. Garrincha foi sabidamente símbolo personificado daquele triunfo esportivo futebolístico que inauguraria um ciclo denso, historicamente curto, porém muito virtuoso em torno do futebol profissional brasileiro a partir de 1958, ciclo interrompido no pós-1970 com o recrudescimento da ditadura militar. Sempre é bom lembrar que o selecionado voltaria a vencer uma Copa do mundo, megaevento que fomenta nacionalismos e define o futebol dentro daquilo que circunscrevo como esporte-nação, somente em 1994, num país já vivendo sob a redemocratização. Considerados os triunfos esportivos de 1958, 1962 com 1994 e 2002, restaria o de 1970 como sendo a única conquista imersa inteiramente na atmosfera estética, moral, administrativa e política implementada pelo regime autoritário tecnocrático militar.

Sustentam que o fim da existência física de Garrincha marcaria historicamente os estertores de toda uma era do futebol, embora o senso comum midiático asseverasse que seu estilo fosse mesmo resultado de manifestação solitária, desinteressada e brejeira de sua maneira de jogar, em parte fruto das assimetrias ergonômicas de seu próprio corpo. A sócio-historicização dos autores corrigiria essa essencializante visão: "Após a morte de Garrincha, o mistério permanecia inteiro para a imprensa, que sempre reduzira as qualidades desse corpo em ação a um fato único, de ordem individual, ao produto de um dom, de uma espécie de genialidade, ou apenas simplesmente a uma "natureza". Contudo, podemos ver a excelência toda pessoalizada do jogo de Garrincha como uma eficiente transformação e reconversão de um estilo de amador dentro do futebol profissional. Esse jogador, na verdade, é fruto de uma tradição operária de futebol amador, estimulada e praticada dentro de instituições esportivas geridas pelas fábricas ou empresas”. (Lopes \& Maresca, 1992: sem numeração $)^{2}$

O parágrafo derradeiro de $A$ morte da 'Alegria do povo' arremata os argumentos em torno de transformações históricas, mas lança mão das metáforas expandidas sobre a morte física do jogador para complementar e delinear o entendimento de todo um período, deixando transparecer um temor resignado diante da morte histórica:

(...) o sentimento de perda era gerado não apenas pelo fim da grande época do futebol brasileiro, mas também pela intuição de que estavam completamente transformadas as condições sociais que haviam permitido a eclosão de um tal jogador, com um tal estilo de jogo. Através dele desaparecia uma certa classe operária, a das vilas operárias tradicionais. E, de uma maneira mais geral, sua morte simbolizava também o fim de um certo modo de vida popular, cuja lembrança era o único resquício deixado pelo crescimento das dificuldades atuais. À “euforia” dos anos 
1950-1964 - relativamente mais favoráveis às classes populares no plano econômico, político e das liberdades públicas - sucederam-se na verdade uma tristeza e uma certa violência primária que seria tentador associar ao sofrimento gerado pela intensificação da exploração econômica e da opressão política desde a instauração da ditadura militar (violência esta que se manifestou frequentemente durante os anos 70, especialmente sob a forma de tumultos nos trens de subúrbio do Rio e São Paulo). A morte miserável de Garrincha simbolizou ao extremo o desaparecimento dessa "alegria do povo" gerada pelo sucesso dos anos 50, especialmente pela vitória na Copa do Mundo de 1958, na qual o Brasil finalmente se afirmou em escala internacional, ainda que através do futebol, ou seja, de suas classes populares.

Mais contemporaneamente no Brasil, tempos circunscritos pelas crises da representação política que alcançaram as manifestações de rua a partir de 2013, espécie de "esfriamento" do pacto constituinte instaurado em 1988, e que trouxe consigo reavivamentos de signos políticos, corporalidades autoritárias, bricolagens semióticas e ressemantização conceitual de acontecimentos relacionados ao período ditatorial $^{3}$, percebe-se o quanto interpretações históricas tomadas por alegorias no presente podem contorcer ou dobrar sobre si mesmas, sugerindo a ocorrência de nexos reiterativos nos quais os eventos se recompõem em novos cenários. O que coloca dúvida razoável sobre se, exceção feita aos corpos, eventos históricos que se creem singulares, de fato, "morrem" apenas uma vez.

Aprende-se com Lévi-Strauss o quanto pode ser problemático manter seguras as fronteiras rígidas entre narrativas míticas, histórias "frias" e “quentes" e, aqui no caso, versões históricas ou, mais precisamente, o fosso entre historicidades e historiografia (Goldman, 1999; Saéz, 2008) ${ }^{4}$. O autor, em várias oportunidades, oferece essa provocação. Fiquemos com a que segue:

(...) quando tentamos fazer história científica, fazemos porventura algo científico ou adotamos também a nossa própria mitologia nessa tentativa de fazer história pura? (...) Assim, se se tomarmos dois relatos de historiadores, de diferentes tradições intelectuais e com alinhamentos políticos diversos, de acontecimentos como a Revolução Americana, a guerra Franco-Inglesa no Canadá ou a Revolução Francesa, não ficamos de fato nada espantados ao constatar que eles não nos contam exatamente a mesma coisa (Lévi-Strauss, 1989a:63).

Essas questões aparecerão como inspirações para os relatos e experiências sensíveis que assumirão aqui a condição de fragmentos etnográficos, convertendo "mortes esportivas" e alegorias correlatas numa espécie de "etnografia do temor". O (des) 
encontro entre duas experiências extemporâneas entre si - uma vivida conscientemente na forma de observação etnográfica (o funeral do automobilista Ayrton Senna no longínquo ano de 1994) e outra em alguma medida espectral e fortuita (em torno da participação de historiadores, antropólogos, sociólogos, educadores relacionados aos estudos sobre esportes num evento de caráter multidisciplinar ocorrido em 2018) - produzirá uma espécie de superfície descontínua, tensionada numa economia das emoções manifesta em função de pontos de vista sobre noções como esporte-nação, nacionalismo e o papel do futebol como alegoria política e acadêmica.

É provável que $A$ morte da 'Alegria do povo' ostente justificadamente a fama de ser um dos primeiros, senão de fato o primeiro texto a tratar o tema da morte esportiva do ponto de vista das ciências sociais brasileiras, expandindo os significados da morte. Exceções à prosa rodrigueana, que abriu este artigo, muitas vezes o fato da morte, no caso relacionada às narrativas esportivas, não excede os limites de um dado de realidade, aparecendo não raramente como informação biográfica, fazendo cessar o devir da continuidade e da relação de intimidade entre o ser individual e o coletivo.

Já há algumas décadas, as humanidades seguem dedicando continuado investimento nos fenômenos esportivos, estreitando na forma de múltiplos diálogos e iniciativas o campo mais geral dos estudos sobre esportes com outras searas acadêmicas, pensando particularmente na relação entre as ciências humanas com a educação física, psicologia, jornalismo. O Simpósio Internacional de Estudos sobre o Futebol realizados quadrienalmente desde $2010^{5}$ atesta essa multiplicidade de perspectivas. Retornarei ao tema do Simpósio mais adiante, especialmente ao dia em que ocorreu a última sessão da sua terceira edição ${ }^{6}$ para fixá-lo não simplesmente como locus inerte de divulgação de resultados de pesquisas, mas como sujeito actante ${ }^{7}$ imerso nas movimentações políticas que o circunstanciaram. O modo como o Simpósio foi enredado a uma associação de agentes e acontecimentos trará, do ponto de vista etnográfico, outra perspectiva sobre como a antropologia das práticas esportivas pode enfrentar o tema da morte esportiva, tendo em vista o caráter entrópico dos fatos históricos que se precipitaram no desenrolar do evento.

Ainda mais, tomar o Simpósio como pessoa é compreendê-lo como sujeito e objeto ao mesmo tempo, cuja temática do futebol por ele abordada produzirá novas alegorias acadêmicas e políticas num contexto que foi marcado pela renhida campanha eleitoral para presidência da república ocorrida em 2018.

De modo geral, mortes físicas e simbólicas ganham relevo nos estudos sobre esportes porque podem ser amparadas num amplo espectro narrativo, literário ${ }^{8} \mathrm{e}$ 
científico e, particularmente de alto rendimento nas análises antropológicas, aproximando o domínio sensível ao inteligível ${ }^{9}$. A morte, em que pese sua singularidade existencial, consiste num fato social total na medida em que abraça a todos, seja porque obviamente somos corpos destinados ao desaparecimento, mas sobretudo porque também somos portadores de perspectivas, teorias, saberes que metaforicamente "fenecem" no intrincado jogo convencionalmente redefinido que chamamos de "realidade". Mas ao contrário dos corpos, representações e esquemas conceituais, tais como valores, sentimentos e ideologias políticas, também podem ressuscitar, trapaceando não somente a finitude do corpo como também uma dada concepção mais linear de história, se concebida apenas como um sistema aberto e quente ${ }^{10}$.

A morte, portanto, aproxima o natural do cultural, o psíquico do simbólico, a metáfora da metonímia, bem como promove o encontro entre perspectivas que lidam com os corpos e suas potencialidades, no caso lúdicas e esportivas, e as noções socioantropológicas de corporalidade e pessoa.

A morte ou manifestações estéticas relacionadas a ela intervieram em muitas atividades corporais e lúdicas mais refratárias de serem delimitadas no estrito universo normativo dos esportes, tais como as touradas. Os processos de esportificação ${ }^{11}$, por sua vez, aboliram paulatinamente a violência física e as possibilidades da morte em ato, excetuando em circunstâncias fortuitas, como substrato último na produção das emoções e sociabilidade, tais como descreve amplamente os trabalhos de Norbert Elias (1992). Para esse autor, um primeiro movimento "civilizatório" nessa direção foi a invenção da caça à raposa, em que a matança foi substituída pelo prazer da captura de um animal por outro, encarnados no par cão-raposa. As touradas e outras manifestações próximas ou aparentadas manteriam o tônus sacrificial e a diferença de potencial simbólica entre homem e animal. No importante ensaio Espelho da Tauromaquia, Michel Leiris ao distanciar a tauromaquia dos esportes, mesmo daqueles que envolvem risco de morte, cita de passagem o automobilismo, afirmando que

podemos estar certos de que, em comparação a qualquer outra espécie de proeza física realizada segundo regras e sob ameaça de um acidente sério, o que confere esse valor singular ao desempenho do torero é seu lado essencialmente trágico: todas as ações executadas são preparativos técnicos ou cerimônias para a morte pública do herói, que não é outro senão esse semideus bestial, o touro (Leiris, 2001:18) $)^{12}$.

A longevidade (ou seria a imortalidade?) das metáforas sobre a morte espor- 
tiva pode motivar as análises a inquirir tanto narrativas do passado quanto ações presentes e futuras, inovando as narrativas históricas mais uma vez, no sentido que Lévi-Strauss parece sugerir, ou seja, mais próximas de um “nível intermediário" em que estaria garantida a precipitação de eventos singulares. Isso evidencia a vocação ideográfica da história (Saéz, 2008:135), portanto tomada num nível consciente e a permanência de "fatos" inconscientes continuadamente ressignificados:

Assim, um mito que se transforma passando de tribo a tribo, finalmente se extenua, sem por isso desaparecer. Duas vias lhe permanecem abertas: a da elaboração romanesca e a da reutilização pra fins de legitimação histórica. Por sua vez, essa história pode ser de dois tipos: retrospectiva, para fundar uma ordem tradicional sobre um passado longínquo; ou prospectiva, para fazer desse passado o início de um futuro que começa a desenhar-se (Lévi-Strauss, 1989b:274).

Dessa perspectiva, parece que fabulações e fatos inscritos no tempo alimentam historicidades e o domínio propriamente espacial das ações concretas, celeiro inesgotável dos encontros etnográficos. E realocadas num mesmo movimento, diria que se misturam nas ações e práticas dos agentes para produzirem múltiplos efeitos; e esse será o argumento que se seguirá, sem antes ainda retomar o tema da morte esportiva sob dois pontos de vista: um intelectual e outro estético.

\section{Mortes esportivas e narrativas intelectuais}

Uma conhecida expansão interpretativa das metáforas em torno das representações da morte esportiva pode ser notada nas análises que tomaram os esportes como situações reveladoras de dramas sociais. A morte aparece como operadora metafórica e não necessariamente evento singular, quer dizer, morte somente atrelada ao corpo, senão para assumi-la como função referencial simbólica. Dessa perspectiva, a morte também não se coloca como epifenômeno, isto é, diluída em significados sócio-históricos mais centrais, tal como evocada no alentado artigo de Lopes e Maresca.

E liberta do corpo e da narrativa diacrônica, será associada aos movimentos reiterativos rituais, em que derrotas metaforizam mortes esportivas de inspiração "estruturante”, mobilizando categorias simbólicas regionais. A totalidade empírica no caso seria o Brasil tomado do ponto de vista das performances dos selecionados brasileiros, cujo marco foi a derrota na copa do mundo em 1950, um lugar privilegiado de análise. Acrescenta-se outra derrota aqui na busca de um contraponto, a mais 
recente ocorrida em 2014, ambas, como se sabe, foram Copas realizadas no Brasil.

Um rebento acadêmico dessa perspectiva, tomado como outro texto inaugural dos estudos mais gerais sobre futebol na literatura acadêmica brasileira, mobilizou a metáfora da morte esportiva como dispositivo dramático e ritualístico. O conhecidíssimo volume Universo do Futebol, coletânea assinada por Roberto Da Matta, Luiz Felipe Baêta Nevez, Simoni Lahud Guedes e Arno Vogel, é o exemplo paradigmático de abordagem, até então inédita na literatura em ciências sociais, relacionando os esportes ao tema da morte simbólica, contribuindo no plano acadêmico para fixar o futebol como lídimo esporte-nação. Arno Vogel assim escreve sobre a derrota de 1950:

A ideia de morte está claramente delineada na consciência dos atores do drama. Ninguém deixa de se referir a ela. Há os que mencionam os suicídios. Outros qualificam o silêncio, dizendo que era como se alguém muito importante tivesse morrido, um presidente da república, ou algo assim. Houve um, mais ingênuo, que colocou as coisas na ordem direta: A mãe pátria tinha morrido! (...) O que aconteceu à saída do Maracanã foi uma procissão fúnebre, em torno do sagrado nacional. E isso pode ajudar, e muito, a compreender o que significou, para os brasileiros, a derrota na Copa de 50 (Vogel, 1982:92).

Já em relação a 2014, podem-se divisar algumas fronteiras do modelo da dramatização, nas quais parecem esgotadas as funções ritualísticas consensuais em torno do esporte-nação na medida em que se renovaram os usos políticos do futebol numa sociedade em crise. É bom destacar que tal modelo nasceu de uma crítica e crise epistemológica no interior dos estudos sobre os esportes, decretando a morte de modelos deterministas de explicação do futebol num momento em que o Brasil vivia a abertura política e a retomada democrática ${ }^{13}$. Já 2014 marcará a crise política dessa mesma democracia num momento em que os estudos antropológicos gozavam de autonomia e mais amparo institucional após sucessivas políticas de expansão da pesquisa no sistema universitário público.

2014 contextualizou uma copa ${ }^{14}$ mobilizada em torno dos supostos distúrbios comportamentais que incidiram sobre as performances dos jogadores aturdidos em momentos decisivos, tomados na mídia por instáveis e “chorões”, reavivando conhecidas fórmulas psicologizadas sobre o temperamento do brasileiro ${ }^{15}$. Na Copa de 2014, torcedores politizaram a paixão esportiva tanto à direita quanto à esquerda do espectro ideológico, fragmentando e tornando mais pragmático e negociado o suposto nacionalismo psico-antropológico que parecia estabilizado e que fazia coe- 
xistir futebol e sociedade na chave da identidade nacional.

E profissionais da mídia não raramente se surpreenderam com os níveis de incredulidade com que se manifestavam os torcedores diante do esporte-nação, fracionando-o em pequenas mil mortes políticas a cada ação coletiva e movimentos sociais, que bradavam contra autoritários planos de mobilidade urbana propostos pela não menos autoritária lei geral da copa ${ }^{16}$. Espocaram manifestações e palavras de ordem contra autoridades governamentais, comissão técnica, e aqueles considerados os verdadeiros donos do megaevento, conglomerados empresariais capitaneados pelos emaranhados corporativos produzidos na FIFA.

Dentro de campo e envolto em toda uma economia simbólica das lágrimas ${ }^{17}$, um selecionado doente ou moribundo escutou, sobretudo de fora das arquibancadas, pois dentro manifestavam somente turistas e torcedores selecionados pelo poder econômico, palavras de ordem e de morte que apregoavam o fenecimento do futebol brasileiro. E os resultados esportivos caíram diante dos olhos torcedores na derrocada de um estilo de jogo motivacional encarnado no técnico Felipão. Fora de campo, os coletivos "Não Vai ter Copa" e a indução do jogo político rumo à derrocada de um determinado governo já àquela altura politicamente açodado e economicamente claudicante, arrematavam o insucesso esportivo e político daquela edição da Copa do mundo, reconhecida também pelo rol de legados negativos. O futebol como representação ou dramatização ("damattização") do nacional parecia que deixava de se manter imune e refratário diante das possibilidades das mortes políticas e esportivas. A FIFA e a CBF, nos anos subsequentes, seriam alvos de investigações internacionais que levariam à destituição de suas cúpulas dirigentes.

Por último, é preciso indicar, a título de menção, que não somente os jogadores, mas também dirigentes, políticos, governantes ou instituições futebolísticas (federações estaduais, CBF, FIFA) estiveram ainda que indiretamente enredados à problemática da morte esportiva na literatura acadêmica. É no âmbito dos espectadores que se reencontram os riscos da morte física, portanto mais distantes do modelo da dramatização que se movia analiticamente pelas simbolizações do esporte-nação. O tema das modalidades de sociabilidade trará a crueza dos enfrentamentos em nome das adesões torcedoras em projetos políticos coletivos que alcançavam os fundamentos das vontades corporalizadas por autonomia numa dimensão metonímica sacrificial paroxista.

O acirramento e ciclos de violência entre torcedores mascararam outras adesões e formas de morte e violências menos espetaculares, porém não menos danosas em 
relação aos seus efeitos institucionais (aparatos repressivos, guerras econômicas e políticas entre entidades esportivas, relações trabalhistas), provavelmente vitimando tantos outros protagonistas, assim como fizeram com o próprio Garrincha. Já a violência física seguida de morte entre torcedores tem origens no recrutamento dos aficionados não somente em função dos arranjos institucionais torcedores que gravitam em torno dos clubes, mas em relação aos arranjos inerentes à noção de esporte-nação, com a demarcação de seus territórios existenciais e práticas indutoras de uma economia política eivada de ilegalidades e violência nada estranhas aos mecanismos de produção de riqueza, poderes e identidades no seu interior.

O apego aos micropoderes desde a constituição dos vários modelos de sociabilidade torcedora - Torcidas Organizadas (Toledo, 1996), pertencimentos clubísticos (Damo, 2002), Torcidas Jovens (Holanda, 2012), e mais recentemente coletivos identitaristas - reposicionou essa miríade de práticas voltadas para a ação e reprodução desses coletivos em estreita relação política com outros atores no fluxo dos arranjos esportivos profissionais. Não obstante o quanto dessa violência e as mortes dela decorrentes alimentaram essa dinâmica aspiralada e dissonante, como recursos identitários não tornaram esses coletivos populares mais homogêneos, sequer instâncias apenas orientadas para e pela violência, em que pesem as tentativas em transformá-los em segmentos estigmatizados e apartados do emaranhado futebolístico profissional e de espetáculo.

\section{Morte como estética narrativa na crônica esportiva}

Aproximações metafóricas e usos da ideia de morte simbólica relacionadas aos esportes e por extensão às representações sobre nacionalismo e esporte-nação condensaram-se também nos jargões jornalísticos e em textos acadêmicos vinculados a esse vasto e fragmentado campo. Rotinizados em sucessivas tentativas de reprodução de estilos orientados por cronistas de renome, textos jornalísticos e coberturas esportivas em geral não raramente flertam com estilos literários na condução das coberturas amparadas na relação entre tragédias e devir histórico. Os irmãos Rodrigues, Mario e Nelson, consistem em exemplos paradigmáticos dessa empreitada estética. Cabe um exemplo solto, mas atado à fórmula e aos argumentos que sustentam a ideia de proximidade entre esporte-nação e morte esportiva. $\mathrm{O}$ trágico acidente de Ayrton Senna revelado no fragmento que segue exemplifica essa relação simbiótica entre nacionalismo e tragédia física:

É terrível fotografar o tormento de um indivíduo solitário que, por exemplo, perdeu 
seu único ente querido. E também a aflição de uma família com o falecimento de um parente, filho, mãe, pai, irmão. E, ao longo de anos da minha profissão de jornalista me deparei com isto. Mas dessa vez, estava diante de um sofrimento igualmente intenso, mas coletivo: uma nação inteira sepultar um ídolo (Orlando Brito, fotojornalista) ${ }^{18}$.

Foi a prosa de Nelson Rodrigues, sobretudo, aquela que se elevou à condição paradigmática no interior do jornalismo esportivo e talvez aquele autor entre tantos outros que mais flertou com o tema ou mais metaforizou as sensações da morte esportiva em suas crônicas, amparando inclusive as interpretações do universo acadêmico na compreensão das representações sobre o futebol e por consequência sobre os possíveis brasis dele depreendidos. Não é exatamente uma sociologia das representações em torno da morte que aparecem em suas crônicas, mas uma estética da morte ou a ideia de negação a ela vinculada, cuja possibilidade de apreensão dos sentidos mais subjetivos do jogo reposicionam a morte como grande inimiga a ser debelada ao lado da falta de fé, traço psicológico cunhado pela expressão "complexo de vira-latas", aludindo ao problemático caráter nacional e outras projeções sociopsíquicas enunciadas e experimentadas pelo cronista.

O apego ao futebol como uma qualidade impressa nos corpos dos jogadores e torcedores brasileiros não estaria imune aos perigos e ataques constantes da derrota, transfigurada em morte esportiva. Derrota aparece constantemente em Nelson Rodrigues como morte esportiva e ao mesmo movimento morte moral, ainda que passageira, assombrando e religando o selecionado ao povo brasileiro.

Não obstante, derrota ainda não pode ser confundida com morte ${ }^{19}$, essa sim um sintoma de paralisação perpétua de um estilo de jogar, colocando à prova a relação simpática entre nação e esporte. Ademais, a morte (física ou simbólica) como representação social que inflamou os estudos acadêmicos não coincide exatamente com a "morte passageira" (a derrota) intuída na subjetividade esportiva dos textos rodrigueanos. A relação que podemos estabelecer entre sua prosa com os primeiros estudos acadêmicos, a levar em conta o marco de Universo do Futebol, se dá por diferenciação complementar, quer dizer, tendo a morte ou sua possibilidade como dramatização que levou tanto cronistas quanto pesquisadores a diferenciarem seus métodos, mas ao mesmo tempo complementarem suas abordagens a respeito do futebol como símbolo dominante, ou como venho denominando, conceituado como esporte-nação.

Nelson Rodrigues, espécie de moralista esportivo, não pretendia fazer sucumbir a sua escrita ante as fraturas ou pequenas mortes do nacionalismo a cada derrota. 
Tanto é que apaixonadamente ajudou a erigir esse nacionalismo esportivo estando à frente na militância jornalística e literária. Já os estudos acadêmicos subsequentes ficariam mais atentos aos desdobramentos, processos e tensões inerentes aos dilemas enfrentados pelo esporte-nação em suas cismogêneses ${ }^{20}$ com o "nacional". A condição pré-existente e a-histórica do futebol como um mito culturalista passaria a fabular as transformações da relação entre esse esporte e a dita sociedade brasileira. A morte de Nelson Rodrigues em 1980 deixaria uma lacuna difícil de ser reposta na crônica esportiva. Decretar a "morte" da potência identitária do futebol via trabalhos acadêmicos nas décadas sequentes parecia um caminho sem volta, sobretudo num ambiente de segurança democrática onde novas formas de expressão de outros futebóis paulatinamente foi ganhando forma e substância na arena pública numa trama de demandas por novas expressões corporais e subjetivas.

\title{
Etnografias (quase) mortais
}

\begin{abstract}
"Em nosso tempo, o fanatismo do futebol invadiu o lugar que antes estava reservado somente ao fervor religioso, ao ardor patriótico e à paixão política” (Eduardo Galeano)
\end{abstract}

Enfim, alcanço o problema que gostaria de tratar aqui, o encontro entre fabulação e história, metáforas e metonímias, ou esportes como metáforas (de senso comum, literárias ou acadêmicas) com os esportes vividos como metonímia em experiências concretas e sensíveis. Mantenho fiel às observações que se seguem dentro de uma análise que se pretende simbólica, mas não creio que as metáforas possam servir como únicas figuras de linguagem na expressão desse simbolismo. $\mathrm{Ou}$ não bastam, apenas. É preciso tomar os esportes, suas mortes e ou "ressureições" como metonímias e extensões das relações que enunciam no transcurso de realidades contextuais. Aqui jogo também não é tomado por metáfora para falar de outra coisa, da vida, da cultura brasileira; jogo é vida e acontecimento, precipitação, algo que pode ser destacável da própria vida, fragmentos e negociações de experiências que fazem parte da pessoa, seja a pessoa torcedora, seja a pessoa intelectual, seja a pessoa compósita e actante, enfim, qualquer uma que incorpore os esportes nos cálculos de suas extensões identitárias e tomadas de posição política.

É dessa forma que passo a narrar comparativamente algumas impressões, sensações, diria mesmo corporalizações a partir de duas experiências ortogonais con- 
vertidas e entrelaçadas aqui em casos etnográficos: minha presença na última sessão do III Simpósio Internacional de Estudos sobre o Futebol realizada no Museu do Futebol, em 2018 e no funeral de Ayrton Senna ocorrido em 1994. Dois casos nada simetrizados ou comparáveis entre si, seja do ponto de vista de suas estruturas narrativas internas, sejam do ponto de vista das aproximações e formalizações conceituais que possam reter. Descontinuados histórica e sociologicamente cumprem oferecer a produção metonimizada de algumas sensações precipitadas na biografia de quem os vivenciou, aqui no caso o antropólogo. Concretamente falarei de temores e suspeitas, expectativas, ou mesmo formas de reter o temor ou apreensão como sintomas ou virtualidades da ocorrência de alguma espécie, aí sim, de mortes esportivas. Temores, apreensões e expectativas formam uma tessitura ou aderência corporal e subjetiva em torno desses dois acontecimentos, todavia não serão narrados aqui como "contextos para" alcançar a objetividade histórica, pois são tomados por narrativas autossituadas ou "confissões" que estabelecem a passagem dos fatos históricos em etnográficos.

Sem se fazer perder em labirintos de impressões apenas subjetivas e incomunicáveis, esses casos poderão deixar rastros para que retomemos problemáticas produtivas em pesquisas “sociais” sobre esportes. Até mesmo porque as percepções (de senso comum, socioantropológicas, históricas) que elaboramos sobre os esportes devem passar pela tradução ou experiência, primeiro, das percepções sensoriais ou aquilo que chamaria aqui de política da sensibilidade etnográfica, que, ademais, em nada está divorciada dos processos mais abrangentes.

Receios, suores nas mãos, palpitações, hesitações, paixões, virtualizações da morte podem ser bons indícios para acolhermos o ponto de vista de uma etnografia do temor sem cair necessariamente no pântano do subjetivismo. Sigamos então com os relatos.

\section{Nacionalismo como "espetáculo da morte"}

Pedi carona ao historiador e professor Flavio Campos, um dos coordenadores do Ludens, tão logo acabou a última sessão de toda uma intensa semana de atividades ocorridas no referido simpósio, distribuído durante a semana em três locais: departamento de História da USP, campus Butantã; SESC “fábrica” Pompeia, localizado no bairro de mesmo nome; e o Museu do Futebol. Aquela última sessão fora direcionada para que ocorresse nas dependências do Museu do Futebol, consagrado espaço expositivo, de pesquisa e de lazer contíguo às arquibancadas do glamouroso 
Estádio do Pacaembu, no bairro de mesmo nome, também na cidade de São Paulo.

O museu aproveitava o encerramento do simpósio para inaugurar uma curiosa exposição sobre rivalidades torcedoras, tema um tanto indigesto de ser esteticizado, sobretudo em instituições privadas de fomento à cultura, que pensam o futebol a partir da grande narrativa histórica e identitária nacionalista. Embora o museu seja do ponto de vista defendido aqui mais um dispositivo que ampara o status do futebol dentro daquilo que estou definindo como esporte-nação, a política desse Museu em específico guarda distinções sensíveis em relação ao conjunto museográfico ou colecionismos que amparam as narrativas da memorabilia em torno das práticas futebolísticas no Brasil ${ }^{21}$.

E em se tratando do comportamento torcedor, rivalidades têm sido alocadas há décadas nas narrativas ambíguas e pantanosas dos discursos civilizatórios em torno da repressão e judicialização. Eu e o professor Flavio fizemos um sobrevoo na exposição e após ligeira visita rumamos para o seu carro na intenção de alcançar um metrô mais próximo, onde nos despediríamos. A brincadeira era se encontraríamos o carro dele intacto, já que horas antes e coincidindo com os últimos trabalhos do referido simpósio a praça Charles Muller, amplo espaço contíguo ao estádio, havia servido de palco para a manifestação político-partidária da então candidata a deputada federal pelo PSL, logo eleita com expressiva votação, Joice Hasselmann. O motivo da brincadeira era que o carro exibia propaganda contrária às posições políticas da então candidata, que reunia em quase metade do espaço da praça muitos correligionários, já àquela altura conhecidos, mas também estigmatizados pela intolerância ideológica. Por sorte o veículo havia sido ignorado e pouco ou nada notado pelos militantes que ali se movimentavam.

Entre algumas dezenas de pesquisadores compromissados com aquela última sessão do Simpósio se podiam notar muitos participantes usando camisas de times do futebol brasileiro, de times profissionais estrangeiros, semiprofissionais e até mesmo de clubes amadores, numa paisagem colorida que contrasta com a outra dispersa nos corpos dos militantes recolhidos na praça pela então candidata à vaga na Câmara dos deputados. Os militantes em grande número ostentavam versões da camiseta amarela da seleção brasileira de futebol. Tal contraste era fruto da captura de um símbolo dominante (Turner, 2005), a camisa da seleção brasileira, por parte daqueles que ficariam conhecidos e estereotipados nas manifestações pelo impeachment da presidenta Dilma Roussef em 2016 como “patos”, "paneleiros” ou “coxinhas”. De um lado, pesquisadores torcedores que durante toda a semana discutiram e tematizaram 
sobre identidades, futebóis e diversidade evitaram o uso de uma camisa verde e amarela, alegando o sequestro daquele símbolo vinculado ao esporte-nação; de outro lado, militantes torcedores que no discurso se apresentavam como portadores de soluções alternativas e de resgate moral e ético na política brasileira, imprimindo uma leitura nacionalista que buscava se impor pela via eleitoral.

Outro signo destacável e contrastante naquela paisagem foi a presença de um gigantesco boneco inflável do então candidato à vice-presidência, o general da reserva Hamilton Mourão. Em altura o boneco quase que competia com a monumentalidade da fachada do estádio. Na verdade, o bonecão estava de costas para a fachada e, portanto, para o Museu, direcionado para a saída no sentido da avenida que liga o Pacaembu a outro bairro, a Barra Funda.

Horas depois, ao nos retirarmos do Museu, encontraríamos vestígios da manifestação que há pouco se confrontava política e esteticamente com as tonalidades ideológicas dos participantes do Simpósio. Além do carro do professor, que não exibia sinais de depredação, sobrava daquele evento um varal onde um ambulante misturava souvenires esportivos com camisetas pretas estampando o rosto do então candidato à presidência, Jair Bolsonaro. É preciso acrescentar que Bolsonaro é frequentemente nomeado pelo qualificativo "mito" por seus correligionários, precisamente numa fusão com seu nome, Bolsomito.

Bolsomito é o nome que se popularizou desde que ascendeu à política nacional com sua candidatura. Mito, não exatamente "ídolo", revestiu sua pessoa de uma narrativa que só ganhou os contornos do fantástico e do excepcional ao longo da campanha, sobretudo depois do atentado à sua pessoa que o colocaria na esteira de uma narrativa de morte ou risco e morte, mas que pode ser pensada como morte produtiva em termos eleitorais porque o blindara das controvérsias, dos debates e da suspeita ante suas qualidades intelectuais como potencial dirigente da nação. $\mathrm{O}$ atentado que sofrera ainda em campanha na cidade de Juiz de Fora traria o tema da morte para o epicentro de sua campanha e a narrativa de bolsomito ganharia contornos ainda mais escatológicos com a adesão formal de parte de líderes de segmentos religiosos, evangélicos e neopentecostais, à campanha. Tais adesões não significavam apenas posicionamentos políticos, mas aderência às narrativas que mostravam o então candidato como um messias a invadir a história para promover a redenção do país diante dos descaminhos da democracia e do sistema de representação política. Tratava-se ali de um nacionalismo renovado em curso que chegara à presidência.

Nas semanas que correram ao atentado a campanha de sua candidatura salta- 
ria e fugiria às expectativas do teto eleitoral, alcançando como se sabe a presidência da república. O PSL naquela eleição também saltaria de um deputado para 52 membros na Câmara dos Deputados, apontando para um deslocamento importante e consensualmente tido pelos analistas (jornalistas de editorias políticas, cientistas políticos) como o mais à direita desde o ocaso da ditadura militar e reestabelecimento da democracia participativa.

Em nome de uma posição ideológica baseada no confronto e na dissuasão dos adversários pela ameaça de uso da força e abuso dos jargões bélicos e alusões racistas, muitos bordões foram ouvidos naquele dia na praça Charles Muller ao som dos autofalantes vindos do caminhão alegórico, que convocava os participantes a saírem dali em carreata pela cidade. A retórica do "matar todos os petralhas", bordão do antipetismo que ajudaria a eleger Jair Bolsonaro, logo converteria ameaças e verborragia em reais e difusos enfrentamentos físicos durante a campanha, sobretudo no segundo turno das eleições, divisando constrangimentos morais, físicos, chegando à ocorrência de mortes ${ }^{22}$.

Quase como que acantonados na entrada do Museu estavam os inúmeros pesquisadores de futebol, muitos sabidamente militantes no campo da esquerda, que reativamente contemplavam ou ignoravam a manifestação da candidata do PSL. Aquela sexta-feira anteciparia a grande manifestação dos coletivos femininos e de todo um campo feminista que conclamaria o "ele não" numa manifestação identitarista contra os abusos da campanha de Bolsonaro.

Não seria exagero dizer que a praça acomodando aqueles dois eventos, o Simpósio e o evento político bolsonarista, abria para as possibilidades de enfrentamento, proximidade excessiva, confronto subjetivo existencial e ideológico, e da parte dos pesquisadores que assistiam ao evento político, temores diante dos impropérios nacionalistas e a profusão de metáforas de morte verbalizadas nas falas daqueles que se revezavam nos microfones da manifestação.

Parecia que os pesquisadores se encontravam diante de um dilema de natureza metodológica curioso, embora não problematizado nesses termos, mas vivido ali no encontro fortuito com os militantes: do lado de fora do simpósio vislumbrava-se a história "quente", ou a historicidade misturando seus elementos bricolados, servindo de potência e ação a reavivar ou ressuscitar aquilo que dentro do simpósio se colocava como dimensão problemática ou "fria", ainda de uma perspectiva histórica, sobre as teses ou limites participativos do nacionalismo esportivo ancorado no monotemático futebol como esporte-nação. A fala do historiador Flavio Campos 
ainda no dia anterior ocorrida no SESC Pompeia, reproduzida nas redes sociais e em blogs esportivos mais politizados, atestava de maneira contundente a tensão estabelecida entre o que se discutia no Simpósio, sua urgência política, com parte daquelas vozes vindas das ruas comprometidas com a candidatura bolsonarista.

A manifestação política na praça Charles Mulller era uma resposta antecipatória do que ainda estaria por vir naquele primeiro turno das eleições, ou seja, o recrudescimento ainda maior e adesão significativa da população diante das exibições, muitas delas no formato deletério, mas não menos devastador das fake news, expondo supostos corpos desnudos e de poucos modos que se exibiam nas manifestações do "ele não", movimento de coletivos femininos contrários à publicizada misoginia e homofobia de Bolsonaro. Tais "notícias" alcançariam em massa as redes sociais se contrapondo e promovendo a indignação daqueles que estariam do lado da moral religiosa, dos costumes e preservação da unidade familiar em respostas ao "ele não".

A III edição do Simpósio que ali se encerrava havia escolhido a diferença, os feminismos, os futebóis e as formas identitárias como temas condutores e indutores de políticas públicas, fato que rivalizava com os apelos em nome da nação, pátria livre do comunismo e discursos mais refratários às expressões de gênero que ecoavam dos manifestantes bolsonaristas.

\section{A morte como espetáculo nacional-esportivo}

Já no interior do carro, o professor Flavio anunciou uma fome reprimida e antes mesmo que ganhássemos a rua pelo mesmo caminho que havia transcorrido a carreata política, paramos para comer pastel nas barracas que costumeiramente se alojam no lado oposto da praça. Aquele desvio ou parada de rota foi suficiente para que narrasse ao historiador uma espécie de dejá vú que tivera naquele momento em que contemplava a praça já vazia de pesquisadores e militantes, retomando a rotina de bairro abastado e tendo ao fundo agora somente a paisagem idílica da monumentalidade do estádio. Passei a esboçar uma comparação do que presenciamos horas antes, desde minha chegada em que fui advertido pelo motorista do uber que me conduzia para que tomasse cuidado com a manifestação, afinal precisaria atravessá-la e me misturar ao ajuntamento militante se quisesse alcançar o grupo de pesquisadores que esperavam o início dos trabalhos nas imediações do auditório do Museu.

E ali ingerindo sem muita convicção aquele pastel, comparei o que havíamos visto ainda há pouco com outro evento já mais distante na memória, e passei a lem- 
brá-lo como havia sentido estranhamente quase a mesma atmosfera nacionalista quando presenciei o espetaculoso cerimonial público do funeral do automobilista Ayrton Senna da Silva, ocorrido em outro parque famoso da cidade, o Ibirapuera.

O professor Flavio balançou a cabeça e eu mesmo fiquei sem muita convicção do rigor daquela comparação e passamos a tecer considerações gerais do que havíamos presenciado. A aproximação, na verdade incômoda comparação que me ocorrera de chofre, acabou ficando adormecida. Insisti ainda com o professor que gostaria de esboçar algumas considerações a respeito daquelas sensações que de surpresa se entrecruzavam, mas que não tomavam qualquer relação consciente ou "histórica" de causa e efeito. Afinal, suposta comparação saltara décadas, pulara encadeamentos factuais e descarrilhava a história, parecia se abrigar na esfera das bricolagens ou transformações. Sequer saberia dizer por que me ocorreram naquele momento, mas o fato era que a proximidade entre os dois eventos havia sido antecipada e se agitara no próprio corpo, e tornamos o diálogo mais errático, crispado e irrequieto. Tinha ali nas mãos dois eventos, na verdade três, se considerar o próprio Simpósio como espécie de agente mediador a estabelecer a relação simpática entre os outros dois.

Anos atrás estive nos arredores do funeral de Ayrton Senna, lembrando que o automobilista morrera num $1^{\circ}$ de maio de 1994, e seu velório ocorrera quatro dias após o acidente que o vitimou. Em nada os ritos fúnebres que presenciara in loco e que foram televisionados e repisados na mídia podiam ser comparados ao de Garrincha, descrito no texto de Lopes e Maresca.

Tratava-se de uma cerimônia de Estado para um herói, também chamado comumente na imprensa de mito. As diferenças em relação aos impactos de suas mortes se davam porque Senna era um atleta que estava em plena atividade e forma física quando fatalmente fora vitimado. As circunstâncias de sua morte em plena performance competitiva em nada se comparavam ao fenecimento social paulatino e ostracismo em que se encontrava Garrincha por ocasião de sua morte. No seu funeral de pouca ou quase nenhuma pompa, tomado pelos populares que carregaram à deriva da emoção o seu caixão, os sinais do nacionalismo esportivo haviam esmaecido e embora representante de um esporte muito mais popular que o automobilismo, seu corpo já não podia ser reconhecido como sendo o do Garrincha dos gramados. Era um corpo não estatal, um corpo popular, portanto quase anônimo, já marcado por um certo anonimato, um corpo já dissociado do esporte-nação, porque à revelia do nacionalismo que um dia atiçara em campos nacionais e estrangeiros. Nem é preciso dizer o quanto Garrincha e Ayrton Senna se distanciavam em termos de origem de 
classe e circulação pelos domínios da riqueza.

Já o funeral de Ayrton Senna ganhou proporções assombrosas e inéditas, sobretudo porque mobilizava a massa de populares que se espalhava por todo o parque. Antes havia tomado as ruas, viadutos e se espalharia por toda a cidade no translado do carro fúnebre do aeroporto até o Ibirapuera. Outra comoção seria o translado para o cemitério localizado no bairro gentrificado do Morumbi.

Transcrevo outro fragmento do fotojornalista Orlando Brito que por motivos profissionais cobrira o evento bem mais próximo do epicentro dos acontecimentos:

Um jornalista tem de conter sua emoção diante dos fatos. Mas confesso que nesse dia nem eu e nenhum dos meus colegas cumprimos essa regra. Ainda no aeroporto de Cumbica, vimos o caixão de Ayrton ser coberto com a bandeira do Brasil. Já nesse momento sabíamos que estávamos numa cobertura onde o sentimento da perda e a consequente intensidade da dor marcariam imensamente a história do povo.

Naquele dia e por razões que ainda não saberia equacionar, decidi observar o velório de longe, me afastando do burburinho tomado por bandeiras do Brasil, camisetas da seleção, ambulantes. Ocorria na cidade e ali mesmo no parque mais uma edição da Bienal de São Paulo, prestigiado e tradicional evento internacional de artes plásticas de onde de dentro de suas dependências acompanhei a movimentação da perspectiva de quem olhava através das amplas janelas envidraçadas. Acreditava ser praticamente o único visitante do evento naquele momento de um quase meio-dia ensolarado. Ignorando o conteúdo da exposição, rumei para um andar superior em busca da melhor vista e fiquei um tempo considerável a contemplar solitariamente a movimentação do lado de fora, onde milhares de pessoas iam e vinham a esmo. Mais distante ficava a entrada do prédio da Assembleia, onde se velava o corpo.

Foi como se de dentro da bienal esvaziada de público, algo tivesse convertido o cerimonial que transcorria lá fora num desdobramento da própria exposição ou, ao contrário, como se o silêncio de dentro tivesse alargado o respeito ao luto que ocorria do lado de fora. Um quadro ou instalação que parecia mimetizar a serenidade e o silêncio dos objetos dispostos no espaço interior, mas ao mesmo tempo tornando esteticamente impotentes as provocativas obras ali costumeiramente exibidas em ocasiões de bienal.

Tempos depois esbocei em nota de rodapé na tese de doutorado uma aproximação etnográfica como exemplo dessas interpretações mais “culturalistas", diria 
hoje estatais, daquilo que vira com os olhos um tanto distanciados e objetivantes, portanto de fora e de longe ${ }^{23}$ :

Dentro desta perspectiva do drama, então, outros fenômenos de grande impacto social vinculados ao campo esportivo podem ser interpretados, tais como a morte e o funeral do piloto de Fórmula 1 Ayrton Senna e a vitória do selecionado brasileiro no Campeonato Mundial de futebol, ambos em 1994. Acontecimentos que revelaram, através das dimensões da festa e do luto, toda a dramaticidade de se experimentar o sentimento coletivo de nação para um conjunto expressivo da sociedade brasileira. Momentos em que o sentido da vitória e da derrota, atributos dos esportes por excelência, nortearam o sentimento de dor, de paixão, de perda, por um lado, ou a alegria, o êxtase, o paroxismo, a recuperação da autoestima coletiva, por outro. No dia do enterro de Senna, pude ler em uma faixa carregada por populares nas imediações do parque do Ibirapuera, local onde estava sendo velado o corpo: A gente perdeu um piloto e Deus ganhou Ayrton Senna. Nem naquele momento de exacerbada dor por parte daqueles que ali choravam a morte do ídolo, estes torcedores relegaram o sentido recíproco e profundo da experiência dos esportes. Todos estavam irremediavelmente derrotados pela fatalidade do acontecido, porém, Deus ganhara um símbolo nacional, transformado, de certo modo, em mito de um povo (Toledo, 2000:35).

O parágrafo acima, lido agora retrospectivamente, causa muito estranhamento e distanciamento intelectual sobretudo após ter aproximado quase que inconscientemente aquelas experiências aos acontecimentos vividos na praça Charles Muller. De certa maneira, uma crítica ao nacionalismo ou às formas que o nacionalismo pode assumir historicamente parecem ter produzido um pequeno grupo de transformações em torno desses eventos narrados, uma pequena mitologia que faz aproximar o Simpósio, o evento político bolsonarista e os funerais de Garrincha e Ayrton Senna.

$\mathrm{O}$ avivamento nacionalista e resignado diante da morte de Ayrton Senna, evento criticado pelo piloto Nelson Piquet ${ }^{24}$, conhecido desafeto de Senna, ao justificar que não fora no velório porque aquilo havia se transformado num evento político, aponta para as transformações um tanto cíclicas, ou melhor, helicoidais desse nacionalismo esportivo.

As mobilizações em torno da morte do piloto haviam projetado o Brasil intensamente no noticiário internacional, e a comoção extravasaria em muito os limites do território nacional. Se havia um forte apelo nacionalista diante daquela morte, recuperado inclusive nas análises (Toledo, 2002), o fato era que seu súbito desa- 
parecimento ganhara um alcance muito mais extenso que as narrativas factuais puderam abarcar. A comoção, sem dúvida, reviveu um apelo nacionalista como ingrediente avivado no funeral, mas ao mesmo tempo escondia em sua formatação estatal fraturas que uma análise objetivante e de fora não puderam alcançar naquele momento de luto. Fraturas muito mais evidenciadas e narradas por Lopes e Maresca no modesto funeral de Garrincha. Ali, ao contrário do velório de Senna, torcedores não celebravam um mito, mas sim, e de posse de suas historicidades e na disputa pelo seu corpo, um herói histórico, do passado, sepultado quase sob o silêncio e esquecimento do resto da nação.

\title{
Dobraduras temporais
}

\author{
“O futebol, metáfora da guerra, \\ pode transformar-se, às vezes, \\ em guerra de verdade. \\ E então a morte súbita \\ deixa de ser somente o nome \\ de uma dramática maneira \\ de desempatar partidas." \\ (Eduardo Galeano)
}

É bom lembrar que os depoimentos considerados blasé e demasiado tecnicistas a respeito da tragédia de Ayrton Senna disparados por Nelson Piquet fermentavam um insuspeito incômodo diante daquela que era considerada a maior fatalidade esportiva nacional, morte que dava contornos agora realistas à metáfora da morte esportiva acontecida décadas anteriores no luto simbólico pela derrota futebolística em 1950.

Se a derrota futebolística foi potencializada em mil derrotas e mortes simbólicas subsequentes, a começar pela controversa discussão sobre em quem deveria recair a culpa - em que toda uma discussão factual ou inventada (Moura, 1998) por Mario Filho no aclamado O Negro no Futebol Brasileiro, já fortemente influenciado pelas ideias de Gilberto Freyre que o prefaciou, sobre o lugar dos negros no futebol, de fato acabou abrindo espaço para uma discussão franca sobre racismo na sociedade brasileira $^{25}$-, as projeções nacionalistas emanadas da morte de Ayrton Senna se encerrariam no luto, e apesar dos rebatimentos ou usos políticos condenados por 
Nelson Piquet, aquela morte expressava um nacionalismo acomodado ou reificado na própria formatação do funeral, dando vazão sobretudo às formas estatais de expressão da tristeza coletiva.

Alocada no terreno mais seguro da neutralidade ritual, a morte de Ayrton Senna avivara algum nacionalismo, mas depois dele o automobilismo perderia status simbólico e se retiraria da esfera do esporte-nação. Isso se deu até mesmo porque era o piloto que corporalizava intensamente tal noção a cada vitória a ostentar gestualidades e maneirismos com a bandeira nacional, atitudes muito mais arrefecidas e contidas em pilotos tão vencedores como Nelson Piquet.

Já no Pacaembu, pesquisadores em suas atividades acadêmicas contemplavam, senão a morte, ao menos o estado moribundo das perspectivas analíticas que tematizaram por muito tempo o futebol profissional “cis”, misógino, metaforizado em identidade nacional monolítica. Mas outro problema parecia do ponto de vista acadêmico pouco problematizado, qual seja, o consenso em se pensarem narrativas históricas somente do ponto de vista da história dos historiadores, a história dita científica, perspectiva mais francamente absorvida no simpósio. Voltaremos ainda a esse ponto. E ali naquele III Simpósio, todas as discussões sobre outros futebóis, outros atores ou actantes, futebóis ativistas, futebóis indígenas ${ }^{26}$, movimentos antifascistas de torcedores, futebóis dos deficientes, futebóis generificados, futebóis das mulheres contribuíam para a crítica cultural mais abrangente que apontava para a crise de hegemonia do esporte-nação, rebatimentos dos acontecimentos ocorridos a partir de 2013.

A busca por outras formas de sociabilidade em outros futebóis e dentro da perspectiva que orientou as falas no simpósio confrontava abertamente com a postura e os recursos políticos e narrativos exibidos nas camisetas da seleção na campanha bolsonarista, que pregava abertamente uma estética da força em nome de uma releitura histórica e ao mesmo tempo fabulosa do nacionalismo. A vitória circunstancial desse nacionalismo pode ser considerada uma outra leitura ou dobradura da noção de esporte-nação, o que não necessariamente vá frear outros processos de diferenciação no interior das práticas dos futebóis e dos identitarismos que, se queriam crer, só poderiam vicejar dentro de ambientes mais democráticos. Daí o insuspeito temor que se avizinhava com a proximidade das eleições.

O encontro fortuito dos pesquisadores com a manifestação política relacionada à campanha de Jair Bolsonaro indicava os desdobramentos desse processo, esbarrando nas metáforas da morte de um estado de direito que foi sistematicamente 
vilipendiado na fala autoritária que vinha das campanhas do PSL e seus correligionários. As propostas de combate à violência com a proliferação das armas levariam o Brasil, nas palavras do então candidato, a retroceder aos patamares mais seguros dos anos 1940 e 1950.

A morte física, portanto, real, de Ayrton Senna atiçou as metáforas de um nacionalismo consensual em seu funeral, que redundou no ocaso ou morte simbólica do automobilismo como esporte-nação. Já no ativismo político de um nacionalismo real da parte dos correligionários de Bolsonaro chegava-se à profusão de metáforas de extermínio, violência (física, constitucional, institucional) que acabou espalhada pela campanha em ações metonimizadas por simpatizantes contra gays, transexuais, mulheres, carros do Ibama, universidades públicas. Exterminar todos os dissidentes, os vermelhos e os petralhas, acabar com todas as formas de ativismos no Brasil foram as ameaças que deram o tom da campanha e que se insinuavam como políticas do medo, só apreendidas por intermédio de uma etnografia do temor.

A fala bolsonariana ao embaralhar fatos ditos históricos em alusão a algum princípio metafórico de reversibilidade do tempo histórico, ou seja, sugerir que o país recuasse aos anos 1940 ou 1950, num discurso proferido no BOPE no Rio de Janeiro, trapaceava a narrativa história que, como afirma Lévi-Strauss, consiste num sistema aberto se comparado aos sistemas mitológicos que, estáticos, combinam os elementos mitológicos de infinitas maneiras, "mas num sistema fechado, contrapondo-se à História, que, evidentemente, é um sistema aberto" (Lévi-Strauss, 1989:61).

Nesse mesmo sentido, a alcunha de "mito" como centralizadora de uma potência narrativa agregada ao seu nome, "bolsomito", aparentemente poderia colocá-lo numa posição francamente contra a história dos historiadores, seja porque a despreza como fonte de conhecimento e parece aprender pouco com ela, seja porque a eficácia de seu discurso alimentado no embaralhamento dos fatos e conceitos acabou por sovar uma narrativa bricolada de outra ordem ou espécie de mitologia política autoritária, que alcançou grande eficácia na escolha do voto popular.

As fake news e as opiniões embasadas em frequentes releituras excêntricas da histórica dos historiadores foram marcas de uma nova modalidade de campanha publicitária política que alcançou grande capilaridade. Tais trapaças na historiografia incumbiram-se de ampliar e "esquentar" o embaralhamento das versões e das ações políticas, bem como misturar os fatos e a inventar relações que, do ponto de vista da racionalidade histórica acadêmica, mostraram-se incongruentes e fantasio- 
sas, mas que se revelaram reacomodações bricoladas dos fatos que acabaram, por fim, fabricando um mito ou um herói político, dando-lhe novos sentidos e muita ressonância social.

Para arrematar, gostaria apenas de recolher algumas menções deixadas pelo caminho a respeito das metáforas sensíveis levi-straussianas do frio e do quente, embora e nem de longe pretenda reavivar a essa altura os desdobramentos que motivaram as discussões encerradas na relação entre mito e história. Fixo num aspecto que a etnografia pareceu ter sugerido e que faz reencontrar a noção de cismogênese que essas duas propriedades analógicas parecem evocar.

Isso quer dizer que frio e quente, além de servirem de interpolações para definir em escala planetária os níveis de distinção não exatamente de sociedades "com” ou "sem" história, uma vez que todas a possuem, mas velocidades de transformações históricas em sociedades distintas, descortinando vocações cosmopolíticas e existenciais igualmente distintas, podem se oferecer como recursos metodológicos ou mesmo índices de percepção de transformações das relações no plano da sociabilidade. As metáforas do frio e quente, então, passariam a orientar tomadas de posições políticas não previamente marcadas, abrindo à possibilidade ou exercício de alguma criatividade dialética na relação que podem estabelecer entre si.

Foi nesse sentido que esporte-nação pode ser "esfriado" ou "requentado", historicizado ou fabulado de pontos de vista contíguos, e numa cismogênese simétrica ${ }^{27}$ unir ou separar discursos, performances, tais como observadas entre os acadêmicos do referido simpósio e os militantes políticos naquela proximidade fortuita ocorrida na praça Charles Muller. Importante notar que ao introduzir uma dinâmica cismogênica à suposta dicotomia entre frio e quente, enfatiza-se seu aspecto dialético ou desequilibrado: "Cismogênese não seria, então, uma série de eventos desagregadores que incidem numa entidade substantiva previamente coesa. É uma tendência, uma virtualidade que se efetivará contida e operante no sistema”, e que, portanto, atravessaria a sociabilidade (GEIGER, 2008:51), ou atos de diferenciação contundente, para usar uma expressão de Roy Wagner (Wagner, 2010:16).

E ali naquele "encontro" entre acadêmicos e militantes parecia se impor uma inversão, sem deixar que as propriedades de oposição entre frio e quente fossem diluídas, ou seja, percebeu-se que historiadores, sociólogos, antropólogos tentavam metodologicamente esfriar a noção de esporte-nação como fenômeno histórico devido ao fato desse futebol ter servido e turvado outras realidades em função das narrativas (literárias, acadêmicas etc.) o terem alocado como símbolo dominante. 
Do lado externo ao evento, com as ruas mobilizadas de verde e amarelo pelos militantes bolsonaristas, erigia-se o grande futebol pátrio como signo de uma mudança política restauradora, uma "história retrospectiva", como salientou Lévi-Strauss na discussão sobre a morte ou enfraquecimento dos mitos. Curiosa mudança que, ao mesmo tempo, negava a história e seus fatos, esquentando um futebol idealizado numa bricolagem e fabulação de fatos históricos reivindicando um país que fora grande, mas que se perdeu pelo caminho, e que agora precisaria retomar sua vocação retornando aos anos 1940 e 1950.

Nota-se, portanto, que frio e quente se mostravam com seus sinais políticos trocados, como se aqueles que sempre estiveram a favor da história, os acadêmicos, devessem agora esfriar as fabulações quentes que vinham das ruas e de parte daqueles que, contrários a ela, clamavam por mudanças. Tal inversão estava relacionada às posições políticas em jogo onde os signos da mudança histórica se colocavam no plano dos discursos. Manter a democracia, e de algum modo esfriar a história do esporte-nação ou se aventurar rumo à mudança perigosa porque eivada de alegorias políticas, que, segundo os acadêmicos, traduziam temores autoritários? E em torno das disputas pelo esporte-nação, historiadores, sociólogos e antropólogos tentavam esfriar a história do futebol (matá-lo metodologicamente) para dissolvê-lo em futebóis outros; militantes do PSL em performance tentavam requentar a história e o papel do futebol com fabulações e bricolagens de fatos históricos sobre o nacional.

No caso, esfriar o futebol ou dissolvê-lo em futebóis e por consequência em expressões de identitarismos esteve do lado dos acadêmicos. Já da parte dos militantes, negar ou recontar de maneira fabulosa fatos sem compromissos com a história dos historiadores, tal como se observa nos discursos de Bolsonaro, não impediu que seus militantes no sequestro de um símbolo nacional pudessem requentar sua vocação de unidade nacional e, de fato, fazer história.

Não obstante, possibilidades de inversões e gradações calóricas do modelo, definindo níveis e reposicionando quente ou frio em escalas variáveis, parecem ainda sugeridas por Lévi-Strauss: "As sociedades com história, como a nossa, tem, eu diria, uma temperatura muito mais alta, ou, mais exatamente, existem separações maiores entre as temperaturas internas do sistema, separações essas devidas às diferenças sociais" (Charbonnier \& Lévi-Strauss, 1989:34).

As relações oblíquas entre os eventos passados no Pacaembu com o funeral de Ayrton Senna, estimuladas sob a intensidade do momento político ao final de Simpósio na praça Charles Muller permitem observar também o modo como se move a 
noção de esporte-nação, cujas mortes esportivas o fazem continuamente ressuscitar seja como processo histórico, seja como narrativa "romanesca" de fragmentos históricos; seja como objeto científico ou sujeito político implicado em novas investidas contra ou a favor da história.

Recebido: 07/12/2018

Aprovado: 26/02/2019

Luiz Henrique de Toledo, antropólogo, professor no curso de Ciências Sociais e no Programa de Pós-graduação em Antropologia Social da Universidade Federal de São Carlos (UFSCar). Coordenador do Laboratório de estudos das práticas lúdicas e sociabilidade (LELuS-UFSCar), membro do Núcleo de Antropologia Urbana (NAU-USP) e do Ludens-USP (Núcleo interdisciplinar de pesquisas sobre futebol e modalidades lúdicas). Autor de Torcidas Organizadas de Futebol (Anpocs-Autores Associados, 1996) e Lógicas no Futebol (Hucitec-Fapesp, 2002). ORCID: 0000-0002-5354-5923 Contato: kikeppgas@gmail.com.

\section{Notas}

1. Agradeço aos antropólogos Piero de Camargo Leirner, Carlos Eduardo Costa e Wagner Xavier de Camargo pelas leituras e apreciações críticas de versões deste artigo.

2. Disponível em: http://www.anpocs.org.br/portal/publicacoes/rbcs_00_20/rbcs20_09.htm. 3. Já em 17 de fevereiro de 2009, o jornal Folha de S. Paulo havia relativizado o uso da expressão ditadura, até então largamente utilizada na histografia política, ao se referir ao neologismo ditabranda para cunhar outra circunscrição do período militar. Posteriormente outras vozes se somariam na direção dessa ressemantização: "O presidente do Supremo Tribunal Federal (STF), ministro Dias Toffoli, disse nesta segunda-feira que prefere se referir ao período da ditadura militar no Brasil (1964-1995) como o 'movimento de 1964'”. Sobre reinterpretativismos históricos e relativização da ditadura há muitos dados circulando na internet, o que contribui para novas fabulações em torno do período. Como se sabe, a campanha meteórica de Jair Bolsonaro à presidência se beneficiará intensamente dessas fabulações e desses meios como mecanismo de convencimento dos eleitores. Disponíveis em: https: / /www.cartamaior.com.br/?/Editoria/Politica/O-que-a-falacia-da-ditabranda-revela e https:// ultimosegundo.ig.com.br/politica/2018-10-01/dias-toffoli-movimen- 
to-de-1964.html. Acessos em: 24 out. 2018. Em relação às bricolagens semióticas, alguns artigos e entrevistas de Piero Leirner sobre guerra híbrida e os métodos utilizados na campanha política presidencial em 2018 são boas sínteses nativas de como a história "quente" pode ser requentada a partir da captura e ou embaralhamento de signos. Disponível em: https: / / brasil.elpais.com/ brasil/2018/10/24/politica/1540408647_371089.html. Acesso em: 26 out 2018.

4. A notar uma arguta observação de Márcio Goldman: “(...) creio que ao distinguir e separar a historicidade em si dos discursos que, sob o pretexto de reconhecê-la plenamente, fazem o possível para eliminá-la, Lévi-Strauss abriu o caminho para uma reflexão histórica afastada das armadilhas de todos os evolucionismos e de todas as ideologias celebratórias. Livre das falsas totalidades e das filosofias da história, a historicidade pode reaparecer na forma do acontecimento e do devir, e a história retomar seus direitos como reflexão crítica" (Goldman, 1999:61).

5. No site de apresentação do Ludens (Núcleo interdisciplinar sobre estudos do futebol e modalidades lúdicas), lê-se que se trata de um "centro de investigação científica criado em 2010, na Universidade de São Paulo (USP), que congrega pesquisadores dedicados aos estudos dos jogos e esportes em geral, em particular do futebol. Sediado no Departamento de História da USP, ele reúne professores de universidades paulistas (UFSCar, UNESP, PUC) e outras instituições relacionadas ao tema (como o Museu do Futebol)". Disponível em: https: / /www.facebook.com/LudensUsp/. Acesso em: 22 out 2018.

6. III Simpósio Internacional de estudos sobre o Futebol: Políticas, Diversidade e Intolerância. 26 a 29 de setembro de 2018 .

7. "Em Latour, a ideia de actante se refere a um achatamento das classes epistemológicas modernas (sujeito/objeto, sociedade/natureza) e expressa uma releitura do conceito de social, na medida em que se opõe à noção sociológica clássica de ator social. Por ação social Latour não quer significar apenas a ação do humano, mas fundamentalmente a ação da associação, da combinação de actantes, que podem ser homens, armas, gavetas, instituições, código penal etc. Assim, no plano da ação, a ênfase se desloca mais para os meios, para as misturas, para o ator híbrido, pois a 'ação não é uma propriedade dos humanos, mas de uma associação de actantes' (Latour, 1994: 35)” (Santaella \& Cardoso, 2015:171).

8. Não é o caso agora de apresentar alguma lista de textos literários que relacionam futebol à temática da morte. Para tanto, precisaria estabelecer critérios de seleção. Mas o tema da morte e das aflições tematizam a prosa literária relacionada ao futebol; e cito de relance uma pequena amostra retirada do gosto pessoal. No clássico volume publicado pelo escritor uruguaio Eduardo Galeano (1995), a diminuta crônica intitulada Morte em campo narra a história de um jogador que cometeu suicídio dentro do gramado. O tema da politização da aflição ainda seria tematizado na impactante crônica: As lágrimas não vêm do lenço, no mesmo volume. Em relação a essa última, trago fragmentos na forma de epígrafes em dois tópicos nesse artigo. Um romance em que a morte de um cronista esportivo espreita em vários níveis o desenrolar de biografias entrecruzadas de jogadores com personagens de uma família emocionalmente em frangalhos é O Drible, de Sergio Rodrigues (2013). Em Casquinha não era o que pensávamos, Mario Araújo (2013) trata a morte "natural" de um fictício jogador brasileiro mundialmente conhecido como momento de reapropriação de sua biografia vitoriosa desconstruída após o desaparecimento do atleta.

9. Só para constar, as Ciências Sociais oferecem desde sempre textos fundantes relacionados à 
temática da morte. A bibliografia de formação de parte do campo teórico esteve associada à dimensão sociológica dos fatos sociais, particularmente os morais e jurídicos como representações tipologizadas em O Suicídio, de Durkheim, acompanhado pelas recomendações etnológicas de Efeito Físico no indivíduo da ideia de morte sugerida pela coletividade, de Marcel Mauss, em que o autor chama a atenção para todo um conjunto extenso de fenômenos solidários à morte, sugerindo todo um programa de pesquisas empíricas: "Trata-se de um gênero de fatos que, no meu entender, deveriam ser estudados com urgência, aqueles em que a natureza social reencontra muito diretamente a natureza biológica do homem" (Mauss, 2003[1924]:364). A morte percorreu os estudos empíricos clássicos tanto franceses quanto ingleses, haja vista as monografias africanistas obrigatórias e presentes em todos os cursos de formação acadêmica. Temas antropológicos canônicos tais como magia, feitiçaria, vingança, relacionam-se às noções de morte com as dimensões da política e organização sócio-cosmológicas, renovando continuamente os temas presentes na disciplina. No plano epistemológico, a morte também pode vir travestida de viradas metodológicas, tais como as pretendidas propostas de "morte" da etnografia realista em nome de uma autoindulgência de "nós" mesmos ou, por outro lado, o conhecido movimento de tentativa de "descolonização permanente do pensamento" (Viveiros de Castro, 2015:20) ou tentativa de morte da ciência estatal, que ainda habita o conhecimento antropológico.

10. Voltarei a essa controversa metáfora levi-straussiana do quente, e do frio, em "dobraduras temporais”, última seção deste artigo.

11. Este é uma expressão popularizada pela sociologia histórica de Norbert Elias, desdobrada de outra mais conhecida, "processo civilizador" (Elias, 1992).

12. No contexto brasileiro, há trabalhos que tratam das práticas da tourada que flertam com os maneirismos sacrificiais e que envolvem algum risco de morte, por exemplo, Fantin (2000) abordará o papel ambíguo da farra do boi numa etnografia sobre modernidade urbana na contemporânea Florianópolis; Melo (2012), da perspectiva histórica e tratando do projeto mais abrangente de modernidade à brasileira trará a problemática das grandes touradas ocorridas na efeméride do centenário da independência do Brasil, em 1922.

13. O futebol como "ópio do povo", interpretação que se aproximava ou que havia se estabelecido no interior de abordagens de inspiração marxista sobre os esportes era colocada em xeque por essa corrente teórica que assinalava o caráter situacional dramático do futebol numa sociedade em transformação política como a brasileira desde o final dos anos 1970 .

14. Megaevento ocorrido no Brasil e que esteve em meio às controvérsias e manifestações políticas que alcançariam as ruas na forma dos movimentos de protesto contra os investimentos alocados para o megaevento. “Não vai ter copa”, em princípio agrupando jovens mais à esquerda do espectro ideológico acabou galvanizando até certo ponto uma cadeia de eventos que se desdobrariam em outras demandas e manifestações de massa generalizada contra a situação política do país, momento em que setores menos presentes em manifestações reivindicatórias de rua, tidos por conservadores e mais refratários às performances de rua ganharam projeção e midiatização, complexificando ainda mais a conjuntura política daquele momento.

15. Tais fórmulas são perscrutadas com densidade alegórica na prosa de cronistas de relevo ao menos desde os anos 1950. A propósito, consultar inúmeras crônicas compiladas de Mario Filho no volume $O$ sapo de Arubinha. Os anos de sonho do futebol brasileiro. A respeito desse cronista, 
atesta a historiografia: "Mario Filho exerceu larga influência sobre a área do esporte, da cultura e da política. Na cidade do Rio de Janeiro foi reconhecido como introdutor de um novo modelo narrativo de crônica esportiva e como promotor do Desfile das Escolas de Samba na década de 1930" (Holanda, 2009:163).

16. O Decreto 9527, de 15.10.2018, criaria a Força-Tarefa de Inteligência para o enfrentamento ao crime organizado, porém a Lei Antiterrorismo assinada nos estertores do governo de Michel Temer ainda no ano de 2018 causou temores em parte da sociedade civil dadas as interpretações que apontaram para sua excessiva extensão que a recolocariam na esteira de um autoritarismo punitivo, abrindo brechas jurídicas que poderiam alcançar muitas das formas de ativismo político potencialmente tipificadas como "terrorismo".

17. Para uma análise sobre as lágrimas esportivas nesse Copa, consultar Autor, 2014.

18. Renomado fotojornalista mineiro. Para consultar parte do seu trabalho, vide o site http: / / www. orlandobrito.com.br. Outras informações biográficas e profissionais disponíveis em: http: / / fotoempauta. com.br/orlando-brito/. Acesso em: 19 out 2018.

19. Tal como advertiu o antropólogo Carlos Eduardo Costa na leitura de uma versão deste artigo, chamando a atenção para o fato de que derrota e morte acabariam fazendo parte de um mesmo eixo paradigmático, estabelecendo entre si relações que levariam a um "enfraquecimento" dos aspectos metonímicos da morte, como nas touradas. Novamente recolocamos a problemática da passagem dos jogos para os esportes, tal como discutido mais acima para se pensar nas práticas lúdicas.

20. Cismogênese é um conceito utilizado por Bateson ([1958] 2008) que tenta responder aos processos diferenciantes acumulados pelas interações entre indivíduos ou grupos. Basicamente, o autor estabelece duas formas de interações cismogênicas, a complementar e a simétrica. Sendo a primeira motivada na evolução de relações que embora distintas e opostas, por exemplo condutas assertivas de uns, respondidas com submissão de outros, acabam produzindo uma proximidade entre esses agentes até o limite em que o sistema possa suportar. A cismogênese simétrica evoluiria pelo estímulo de mesmos referentes, quer dizer, as interações levando ao máximo de diferenciação também sob o risco do conflito aberto. Esses processos seriam reversíveis e negociáveis no interior das interações, mas jamais contidos totalmente por estabilidades representacionais sincrônicas ou $a$ priori, daí o rendimento analítico que esses conceitos podem oferecer na análise das relações, perspectivizando noções como identidade, homeostase, representação, símbolos dominantes.

21. A exposição, denominada Clássico é Clássico e vice-versa, teve menos um caráter historicista, enunciando como fio condutor as rivalidades entre times e torcidas em pares de oposição (times versus times distribuídos em vários clássicos populares: Santa Cruz versus Sport; Cruzeiro versus Atlético; São Paulo versus Santos etc.), o que conferia um outro modo de rearranjar a narrativa esportiva. Sobre o Museu do futebol consultar Alfonsi (2018).

22. A morte de Moa do Katendê, mestre reconhecido nacionalmente no universo da capoeira e da música popular baiana, por esfaqueamento em virtude de entreveros políticos, constrangeria ainda mais o processo eleitoral. Disponível em: http: / /atarde.uol.com.br/bahia/salvador/noticias / 2000649-mestre-moa-do-katende-e-morto-a-facadas-apos-discussao-politica-em-salvador. Acesso em: 26 out 2018. O término da campanha ainda conheceria mais duas mortes, uma em São Paulo e outra no Ceará por entreveros causados por questões relacionadas aos posicionamentos 
políticos: uma pessoa travesti no largo do Arouche (SP) ferida a facadas e sob gritos espectadores de "Bolsonaro" e um jovem militante numa carreata da outra candidatura em Fortaleza (Pacajus, região metropolitana). Disponíveis em: https://g1.globo.com/sp/sao-paulo/noticia/2018/10/16/travesti-e-morta-a-facadas-durante-briga-em-bar-no-centro-de-sp.ghtml; https://www.em.com.br / app/noticia/politica/2018/10/28/interna_politica, 1000714/homem-e-morto-durante-carreata-pro-haddad-no-ceara.shtml. Acessos em: 29 out 2018.

23. Faço aqui um paralelismo às avessas em relação às recomendações que o antropólogo José Guilherme Magnani (2002) destaca como protocolo metodológico para a realização de boa etnografia, o exercício de um olhar "de perto e de dentro".

24. Disponível em: https://www.youtube.com/watch?v=_9NPl0886E. Acesso em: 21 out 2018. 25. Quem adverte sobre a produção de narrativas a posteriori no contexto de 1950, que teriam culpabilizado os jogadores negros pela derrota do selecionado, é Moura: “Todavia, nas crônicas e reportagens do período, o que mais se enfatiza na explicação do revés brasileiro não é a culpa desses jogadores, não havendo também qualquer alusão às suas características raciais. (...) As crônicas posteriores ao evento, porém, insistem nessa questão. Segundo Mario Filho, na comoção que tomou conta do estádio após a fatídica derrota, alguns esbravejavam e acusavam Flavio Costa, 'mas quase todos se viraram contra os pretos do escrete"”; (...) Esse hiato entre as justificativas apresentadas para a derrota imediatamente após o ocorrido e as construções elaboradas posteriormente, que insistem no ressurgimento das teorias sobre a inferioridade racial brasileira, merece um estudo cuidadoso" (Moura, 1998:144;145).

26. Em tempo, a última sessão denominada "Outros futebóis" contou com os palestrantes Carlos Terena, tematizando sua militância nos esportes indígenas, a historiadora Aira Bonfim, coordenadora executiva do Simpósio e o antropólogo Wagner Xavier de Camargo, cujas falas reiteravam a necessidade da multiplicação das perspectivas para se pensarem os esportes.

27. Lembrar que nesse caso se estimulou o conflito a partir de um mesmo referente; no caso, os usos que militantes e acadêmicos fizeram do futebol como esporte-nação.

\section{Referências bibliográficas}

ALFONSI, Daniela. Réplicas Originais. Um estudo sobre futebol nos museus. (Doutorado em Antropologia Social). Programa de Pós-graduação em Antropologia Social, Universidade de São Paulo, São Paulo, 2018.

ARAÚJO, Mário. Casquinha não era o que pensávamos. In: RUFFATO, Luiz (org). Entre as quatro linhas: contos sobre futebol. São Paulo: DSOP, 2013.

BATSON, Gregory. "Contraste etológico, competição e cismogênese". Naven, Edusp, São Paulo, 2008.

CHARBONNIER, Georges \& LÉVI-STRAUSS, Claude. Arte, linguagem, etnologia. Entrevistas com Claude Lévi-Strauss. Campinas: Papirus, 1989.

DAMATTA, Roberto (et al.). Universo do futebol. Rio de Janeiro: Pinakhotheke, 1982.

DAMO, Arlei. Futebol e identidade social. Uma leitura antropológica das rivalidades entre torcedores e clubes. Porto Alegre: Editora da Universidade, IFCH-UFRS, 2002.

FANTIN, Marcia. Cidade dividida. Florianópolis: Editora Cidade Futura, 2000. 
GAIGER, Amir. “Apresentação”. Gregory Bateson, Naven, Edusp, São Paulo, 2008.

GALEANO, Eduardo. "Morte em campo”. In: . Futebol ao sol e à sombra. São Paulo: L\&PM, 1995.

GOLDMAN, Márcio. “Lévi-Strauss e os sentidos da história”. In: Alguma Antropologia. Rio de Janeiro: Relume Dumará, 1999.

HOLANDA, Bernardo Buarque de. O clube como vontade e representação. O jornalismo esportivo e a formação das torcidas organizadas de futebol do Rio de Janeiro. Rio de Janeiro: Sete Letras; Faperj, 2010.

LATOUR, Bruno. On technical mediation - philosophy, sociology, genealogy. Common Knowledge, v. 3, n. 2, p. 29-64, 1994.

LEIRIS, Michel. Espelho da Tauromaquia. São Paulo: Cosac \& Naify, 2011.

LÉVI-STRAUSS, Claude. Mito e significado. Lisboa: Edições 70, 1989a.

LÉVI-STRAUSS, Claude. “Como morrem os mitos”. In: . Antropologia Estrutural dois. Rio de Janeiro: Tempo Brasileiro, 1989b.

LÉVI-STRAUSS, Claude. “Lévi-Strauss nos 90”. Revista Mana. Rio de Janeiro, v. 4 n. 2, out. 1998. LÉVI-STRAUSS, Claude. “O passar dos dias”. In: . Mitológicas 3 - A origem dos modos à mesa. São Paulo: Cosac \& Naify, 2006[1968].

LOPES, José Sérgio Leite e MARESCA, Sylvain. “A morte da 'Alegria do Povo"”. Revista ANPOCS, n. 20, 1992.

MAGNANI, José Guilherme. De perto e de dentro: notas para uma etnografia urbana. Rev. bras. Ciências Sociais [online]. vol.17, n.49, pp.11, 2002

MAUSS, Marcel. "Efeito físico no indivíduo da ideia de morte sugerida pela coletividade (Austrália, Nova Zelândia)". In: Sociologia e Antropologia. São Paulo: Cosac \& Naify, 2003.

MELO, Victor Andrade. "Modernos? As grandes touradas do centenário (1922) e a reconciliação com Portugal”. In: MELO, Victor Andrade \& SANTOS, João Manuel C. Malaia. 1922. Celebrações esportivas do centenário. Rio de Janeiro: 7 Letras; Faperj, 2012.

MOURA, Gisella de Araújo. O Rio corre para o Maracanã. Rio de Janeiro: Fundação Getúlio Vargas, 1998.

RODRIGUES, Nelson. À sombra das chuteiras imortais. São Paulo: Companhia das Letras, 1992.

. A pátria em chuteiras: novas crônicas de futebol. São Paulo: Companhia das Letras, 1994.

RODRIGUES, Sérgio. O drible. São Paulo: Companhia das Letras, 2013.

SAÉZ, Oscar Calavia. "A história pictográfica”. In: QUEIROZ, Ruben Caixeta de Queiroz \& NOBRE, Renarde Freire (orgs.). Lévi-Strauss. Leituras brasileiras. São Paulo: Ed. UFMG, 2008.

SANTAELLA, Lúcia \& CARDOSO, Tarcísio. “O desconcertante conceito de mediação técnica em Bruno Latour”. Matrized, São Paulo, v. 9, n. 1, jan./jun. 2015.

TOLEDO, Luiz Henrique de. Torcidas Organizadas de Futebol. São Paulo; Campinas: Autores Associados; Anpocs, 1996.

. “Uma contenda acadêmica”. Lógicas no futebol. Dimensões simbólicas de um esporte nacional. Tese de doutorado, PPGAS-FFLCH, 2000.

Futebol, política e religião: a vingança do reacionário (resenha): MARQUES, José Carlos. 
O futebol em Nelson Rodrigues. O óbvio ululante, o Sobrenatural de Almeida e outros temas. 2. ed. São Paulo: Educ, 2012. Disponível em: http://canal6.com.br/faac/ Revista_Faac_v2_n2.pd$\mathrm{f} \#$ page $=101$.

.1x7 50: por onde escoaram as lágrimas da Copa de 2014? In: HELAL, Ronaldo \& GASTALDO, Édison (orgs). Copa do Mundo 2014. Futebol, mídia e identidades nacionais. Rio de Janeiro: LamparinaLEM, 2014.

TURNER, Victor. Floresta de símbolos: aspectos do ritual Ndembu. Niterói: Eduff, ([1967]2005).

WAGNER, Roy. A invenção da cultura. São Paulo: Cosac \& Naify, 2010. 
Mortes esportivas e alegorias políticas: etnografando temores em torno dos esportes-nação

Resumo: Da literatura esportiva aos estudos socioantropológicos, a morte como evento total tem recebido descontinuadas menções como mote de inúmeras narrativas alegóricas, que se interpõe ao futebol como tema. Tomada meramente como dado biográfico ou acontecimento articulado aos processos estéticos e sociais mais abrangentes, a morte pode ser problematizada como evento histórico “quente”, extensão metafórica e recurso metodológico na sistematização de análises sobre simbolismos rituais em torno dos esportes. Neste artigo ela se apresenta como dado etnográfico, que rearticula todas essas outras abordagens. Pretende-se dialogar com alguns desses usos e dimensões em torno do tema da morte, reclassificado como morte esportiva, articulando percepções sobre a noção de esporte-nação. Morte esportiva encerra feixes de narrativas que nascem, morrem e renascem de conjunturas específicas, da cultura esportiva à política, da política ao cultivo do esporte como tema da literatura ou de pesquisas acadêmicas, das narrativas históricas às narrativas cujas fabulações flertam com narrativas ditas "míticas".

Palavras-chave: morte esportiva, antropologia das práticas esportivas, futebol, história quente e fria, bolsonarismo
Sport, death and political allegories: ethnography fears around a sport-oriented nation

Abstract: From sport literature to socio-anthropological studies, death as a total event has received discontinuous mentions as a motto of countless allegorical narratives, which intervenes with soccer as its theme. Taken merely as biographical data or as an event articulated to the most comprehensive aesthetic and social processes, death can be problematized as a "hot" historical event, metaphorical extension and methodological resource in the systematization of analyzes of ritual symbolism around sports. In this article, death presents itself as an ethnographic data, which rearticulates all these other approaches. This article intends to dialogue with some of these uses and dimensions around the theme of death, reclassified as sporting death, interrelating perceptions about the notion of Sport-Nation. Sport death contains bundles of narratives that are born, die and reborn from specific conjunctures, from sport culture to politics, from politics to the cultivation of sport as a subject of literature or academic research, from historical narratives to narratives in which tales flirt with so-called "mythical narration".

Key-words: sports death, anthropology of sports practices, soccer, hot and cold history, bolsonarism 